\title{
AKOMODASI BAHASA DI NAPAN, NUSA TENGGARA TIMUR, WILAYAH PERBATASAN INDONESIA-TIMOR LESTE
}

\author{
(The Accommodation of Language in Napan, Nusa Tenggara Timur, \\ at the Border Area of Indonesia-Timor Leste)
}

Wati Kurniawati

Badan Pengembangan dan Pembinaan Bahasa, Kemdikbud watikurniawati62@yahoo.com

Naskah Diterima Tanggal 21 Desember 2018_-Direvisi Akhir Tanggal 12 November 2019_Disetujui Tanggal 12 Desember 2019 DOI: 10.26499/rnh.v8i2.1119

\begin{abstract}
Abstrak
Desa Napan terletak di wilayah perbatasan Indonesia-Timor Leste yang masyarakatnya bertutur dalam bahasa Dawan dan bahasa Indonesia. Permasalahan dalam penelitian ini ialah mengapa penutur bahasa Dawan berakomodasi, bagaimana arah akomodasi antarbahasa, dan bagaimana penutur yang berakomodasi pada tataran sintaksis berdasarkan jenis kelamin dan kelompok usia? Penelitian ini bertujuan untuk mengidentifikasi tataran sintaksis yang digunakan dalam akomodasi bahasa dan frekuensinya berdasarkan karakteristik responden di Desa Napan, wilayah perbatasan Indonesia-Timor Leste, Nusa Tenggara Timur. Dalam penelitian ini digunakan metode survei. Sampel dalam penelitian ini adalah 72 responden penutur bahasa Dawan, yang terdiri atas 36 pria dan 36 wanita. Hasil penelitian menunjukkan bahwa penutur bahasa Dawan di Desa Napan berakomodasi karena kenyamanan, keakraban, dan untuk menumbuhkan rasa percaya mitra tutur. Penutur bahasa Dawan sangat positif terhadap daerahnya (bahasa Dawan), positif terhadap bahasa Indonesia, dan cukup positif terhadap bahasa negara tetangga, yaitu bahasa Tetun Portu atau Tetun Dili. Penutur bahasa Dawan berakomodasi terhadap bahasa Tetun Portu atau Tetun Dili pada tataran leksikal, frasa, kalimat, dan ungkapan. Berdasarkan jenis kelamin, penutur perempuan bahasa Dawan yang berakomodasi terhadap bahasa Tetun Portu atau Tetun Dili (9,7\%) lebih dominan daripada lakilaki $(8,3 \%)$. Sementara itu, penutur laki-laki bahasa Dawan yang tidak berakomodasi terhadap bahasa Tetun Portu atau Tetun Dili (41,7\%) lebih dominan daripada perempuan (40,3\%). Berdasarkan kelompok usia, penutur bahasa Dawan yang berakomodasi terhadap bahasa Tetun Portu atau Tetun Dili tampak dominan yang berusia $26-50$ tahun $(8,3 \%)$ dibandingkan dengan yang berusia $<25$ tahun $(5,5 \%)$ dan $>51$ tahun $(4,2 \%)$. Di samping itu, penutur bahasa Dawan yang tidak berakomodasi bahasa adalah penutur yang berusia $>51$ tahun $(29,2 \%)$ lebih dominan daripada yang berusia $<25$ tahun $(27,8 \%)$ dan yang berusia $26-50$ tahun $(25 \%)$.
\end{abstract}

Kata-kata Kunci: akomodasi, penutur, karakteristik responden

\begin{abstract}
Napan village is located in the Indonesia-Timor Leste border region whose people speak in Dawan and Indonesian. The problem in this studyare the accommodation of Dawan speakers, what is the direction of their accommodation between languages, and how do speakers' who accommodate at the syntactic level based on gender and age groupThis study aims to identify the level of syntax used in language accommodation and its frequency based on the
\end{abstract}


characteristics of respondents in Napan Village, the Indonesia-Timor Leste border region, East Nusa Tenggara. The method of the study is the survey method with 72 respondents of Dawan speakers which are divided into 36 men and 36 women as the samples. The results show that speakers of Dawan accommodate the language because of the security, familiarity, and growing trust within the speech participants. Speakers of Dawan are very positive about their language, positive about Indonesian language and quite positive about the languages of the neighboring country, namely Tetun Portu or Tetun Dili. Speakers of the Dawan language accommodate the Tetun Portu or Tetun Dili language at the lexical level, phrases, sentences, and expressions. Based on gender, female speakers of Dawan accommodate the Tetun Portu or Tetun Dili language (9.7\%) more than male speakers (8.3\%). Meanwhile, male speakers of Dawan (41.7\%) are less accommodative to Tetun Portu or Tetun Dili than female speakers (40.3\%). Based on age, speakers of Dawan who accommodate the Tetun Portu or Tetun Dili languages dominantly come from the ages of 26--50 years old (8.3\%) compared to ages less than 25 years old (5.5\%) and more than 51 years old $(4,2 \%)$. In addition, speakers of Dawan who do not accommodate the Tetun Portu or Tetun Dili languages are speakers older than 51 years old (29.2\%) more dominant than those aged less than 25 years (27.8\%) and those aged between 2650 years $(25 \%)$.

Keywords: accommodation, speakers, respondent characteristics

How to Cite: Kurniawati, Wati. (2019). Akomodasi Bahasa di Napan, Nusa Tenggara Timur, Wilayah Perbatasan Indonesia-Timor Leste. Ranah: Jurnal Kajian Bahasa, 8 (2), 189-204. https://doi.org/10.26499/rnh.v8i2.1119

\section{PENDAHULUAN}

Pada tahun 1999 Provinsi Timor Timur lepas dari pangkuan Indonesia. Setelah merdeka, Provinsi Timor Timur menjadi Republik Demokratik Timor Leste (RDTL) di Kabupaten Timor Tengah Utara, yaitu di Distrik Oeccusse (Oekusi). Hal ini menyebabkan warga di sana terbagi menjadi dua, yaitu warga yang tetap menjadi WNI dan juga warga yang memilih pindah ke Timor Leste. Di perbatasan Napan-Distrik Oekusi warga kedua wilayah tampak harmonis. Perbatasan Napan berada di Desa Napan, Kecamatan Bikomi Utara, Kabupaten Timur Tengah Utara (TTU), Nusa Tenggara Timur (NTT). Hubungan antara petugas di pos penjagaan Indonesia dan Timor Leste cukup harmonis. Bahkan, kedua pihak saling berkunjung (Wirahadi, 2017).

Warga di Desa Napan dan Distrik Oekusi memiliki nenek moyang dan budaya yang sama. Setiap ada kegiatan adat kedua pihak saling memberi tahu, apalagi jika ada kabar duka. Bahkan, ada warga yang nekat menerobos batas negara atau melalui jalan tikus. Sebagian besar warga di Desa Napan ini tidak memiliki paspor. Warga yang masuk wilayah RDTL harus memiliki pas lintas batas (border crossing movement) yang dikeluarkan imigrasi dan mendapat pengesahan dari TNI dan Polri yang ada di perbatasan Napan. Selain itu, warga Napan pun sudah terbiasa memasuki wilayah Timor Leste. Salah satu faktornya adalah hewan ternak warga Desa Napan, yaitu sapi 
sering jalan-jalan ke wilayah Timor Leste. Hal itu tidak pernah menjadi masalah terkait dengan hubungan warga dua negara. Akan tetapi, yang menjadi masalah adalah penyelundupan bahan bakar minyak (BBM) dan sembako. Beberapa SPBU di Kabupaten TTU sering kehabisan BBM karena terjadi penyelundupan BBM ke wilayah Timor Leste. Harga BBM yang diselundupkan itu menjadi dua kali lipat. Untuk itu, Pemerintah Kabupaten TTU berupaya menghentikannya dan mengeluarkan surat edaran bernomor Ek.541/202/VI/2011 pada Juni 2011 yang berisi bahwa para pembeli BBM dilarang menggunakan alat penampung besar, seperti jeriken dan drum (Wirahadi, 2017).

Setiap bulan warga Timor Leste dari Distrik Oekusi dan warga Napan TTU bertemu di pasar perbatasan. Kedua pihak sekalian beranjangsana. Sekarang sudah ada pasar bersama yang digelar setiap akhir bulan atau minggu keempat pada hari Jumat. Para pedagang dan penjual dari kedua negara bertemu dan bertransaksi di titik batas. Mata uang yang digunakan dalam bertransaksi di wilayah Indonesia dengan rupiah, sedangkan di Timor Leste dengan dolar Australia. Di Timor Leste terdapat barang impor dari Australia dan Napan dikenal dengan madu hutan yang cara pengambilannya lekat dengan adat dan budaya sekitar dan buah asam (Yohanis Anunu, 2017).

Di daerah perbatasan masih minim fasilitas. Salah satu masalah adalah komunikasi. Sejak awal 2010, Timor Leste memasang menara pemancar sinyal. Posisi menara dipasang sekitar dua kilometer dari garis perbatasan. Akibatnya, sinyal telepon genggam yang masuk wilayah itu akan terkoneksi dengan jaringan alat komunikasi milik Timor Leste. Selain Desa Napan, ada tujuh desa lain yang terkena dampak. Jika mengangkat telepon, warga terkena roaming. Jika SMS atau membalasnya, warga terkena biaya Rp4.500,00. Hal ini membuat warga harus bersusah payah mencari jaringan dari provider Indonesia. Jaringan dapat ditemukan setelah berjalan tiga kilometer dari Desa Napan (Yohanis Anunu, 2017).

Data warga Desa Napan berjumlah 1.016 orang. Laki-laki berjumlah 490 orang dan perempuan berjumlah 526 orang. Warga di Desa Napan terdiri atas warga penduduk asli dan eks penduduk Timor Timur yang bergabung dengan WNI. Sebagian besar warga Desa Napan memiliki keluarga di Timor Leste. Yang menarik, sebagian besar di antara mereka tidak memiliki paspor, sehingga keluar masuk menggunakan pas lintas batas (Anunu, 2017). 
Suku bangsa yang besar di Desa Napan adalah suku Siki, Kefi, Nule, Kolo, Eko, dan Eki. Mereka menggunakan bahasa Dawan untuk komunikasi interetnik dan antaretnik. Mayoritas tingkat pendidikan di Desa Napan adalah lulusan sekolah dasar (SD). Di Desa Napan terdapat satu buah sekolah dasar dan satu buah sekolah menengah pertama negeri. Pekerjaan penduduk mayoritas adalah petani (laki-laki berjumlah 227 orang dan perempuan berjumlah 227 orang), pegawai negeri sipil (laki-laki berjumlah 16 orang dan perempuan berjumlah 4 orang), dan pensiun PNS/TNI/POLRI, yaitu lakilaki berjumlah 1 orang dan perempuan berjumlah 4 orang (Anunu, 2017).

Masyarakat di wilayah perbatasan merupakan masyarakat dwibahasa atau multibahasa: bahasa Indonesia, bahasa Dawan, atau bahasa Tetun. Hal ini terjadi karena ada interaksi antarmasyarakat di dua negara, baik dari segi bahasa maupun budaya. Bahasa berperan dalam memantapkan dan meningkatkan ketahanan Negara Kesatuan Republik Indonesia (NKRI). Karakteristik wilayah perbatasan, antara lain (1) terdapat dua bahasa atau lebih dan (2) berlaku dua jenis mata uang (Anunu, 2017).

Rasa nasionalisme masyarakat di wilayah perbatasan dikhawatirkan ada kecenderungan keterikatan dengan negara tetangga sehingga dalam waktu yang lama akan menipiskan rasa nasionalisme. Oleh karena itu, diperlukan langkah sistematis dan terencana untuk mempertahankan keberadaan jati diri bangsa dari unsur kebahasaan di seluruh nusantara. Sebagai jati diri bangsa, nilai-nilai kebangsaan berwujud melalui sikap dan perilaku yang ditunjukkan bangsa Indonesia dalam kehidupan bermasyarakat, berbangsa, dan bernegara. Nilai wawasan kebangsaan perlu ditanamkan pada generasi muda, yaitu (1) penghargaan terhadap harkat dan martabat manusia sebagai makhluk ciptaan Tuhan yang Mahakuasa, (2) tekad bersama untuk berkehidupan kebangsaan yang bebas, merdeka, dan bersatu, (3) cinta tanah air dan bangsa, (4) demokrasi atau kedaulatan rakyat, (5) kesetiakawanan sosial, dan (6) masyarakat adil dan makmur (Pemerintah Kabupaten Cianjur, 2011).

Penelitian masyarakat di wilayah perbatasan telah dilakukan Badan Pengembangan dan Pembinaan Bahasa sejak tahun 2011. Sebagai contoh pandangan dan sikap bahasa masyarakat di Desa Entikong terhadap bahasa Indonesia di wilayah perbatasan Entikong dengan Malaysia tampak positif, bahasa daerah cukup positif, bahasa asing tidak positif. Sementara itu, kemampuan penggunaan bahasa Indonesia 
berkategori baik, bahasa daerah dan bahasa asing berkategori sedang (Mu'jizah dkk., 2012)

Aman dkk. (2016) meneliti akomodasi terhadap aksen standar kebangsaan dalam kalangan informan penutur asli Melayu di Malaysia, yaitu Kuching dan Kota Bharu. Dikatakan bahwa perubahan aksen standar kebangsaan di wilayah yang terpisah dari pusat agak perlahan, tetapi di wilayah yang sama walaupun tegar dialek, akomodasinya agak terlihat. Penelitian ini berkaitan dengan akomodasi bahasa Indonesia atau bahasa daerah di Indonesia, yaitu pelafalan khas yang menjadi ciri seseorang, misalnya, aksen Jawanya sudah tidak terdengar lagi ketika berakomodasi terhadap mitra tutur yang berasal dari Sunda.

Handayani (2016) menyatakan bahwa rata-rata kebanggaan masyarakat Sebatik di Pulau Sebatik terhadap bahasa Indonesia (BI) berdasarkan tiga karakteristik responden, yaitu jenis kelamin, usia, dan tingkat pendidikan menunjukkan perbedaan yang cukup berarti. Berdasarkan jenis kelamin, nilai rata-rata kebanggaan responden laki-laki dan perempuan terhadap BI berada pada kategori yang sama $(3,9)$, yaitu cukup positif. Sama halnya dengan kebanggaan responden laki-laki dan perempuan terhadap bahasa daerah cukup positif. Namun, responden laki-laki memiliki sikap positif yang lebih tinggi, yaitu memiliki nilai rata-rata 3,5 dibandingkan dengan responden perempuan, yaitu memiliki nilai rata-rata 3,4. Nilai rata-rata kebanggaan responden laki-laki terhadap bahasa Melayu Malaysia lebih rendah $(2,5)$ dibandingkan dengan responden perempuan $(2,6)$. Akan tetapi, dalam kenyataan sehari-hari kebanggaan responden perempuan terhadap BI lebih tinggi daripada responden laki-laki yang lebih merasa bangga terhadap bahasa daerah dan bahasa Melayu Malaysia. Salah satu penyebabnya adalah sebagian besar responden perempuan di Sebatik melaksanakan pernikahan beda suku sehingga mereka jarang menggunakan bahasa daerah. Hal itu membuat kebanggaan responden perempuan terhadap bahasa daerahnya menurun. Di sisi lain, mobilitas responden laki-laki ke negara Malaysia lebih tinggi daripada responden perempuan. Oleh karena itu, secara tidak sadar responden laki-laki sering menggunakan bahasa Melayu Malaysia dalam kehidupan sehari-hari. Dari segi usia, masyarakat berusia di bawah 25 tahun memiliki kebanggaan terhadap BI yang lebih tinggi daripada responden yang berusia 26--50 tahun dan di atas usia 50 tahun. Sementara itu, kebanggaan masyarakat perbatasan di Sebatik yang memiliki tingkat pendidikan setara SMP 
terhadap BI lebih tinggi dibandingkan dengan masyarakat yang tingkat pendidikannya SMA, perguruan tinggi, atau tidak sekolah. Namun, di antara tiga karakteristik tersebut terdapat kesamaan, yaitu kebanggaan masyarakat terhadap BI lebih tinggi dibandingkan kebanggaan masyarakat Sebatik terhadap bahasa daerah dan bahasa Melayu Malaysia.

Pola akomodasi bahasa, faktor penyebab akomodasi bahasa, dan fungsi sosial akomodasi bahasa pada masyarakat Kota Pekalongan etnis Jawa-Tionghoa-Arab dalam ranah perdagangan dikaji oleh Adyana dan Fathur Rokhman (2017). Pola akomodasi bahasa yang dilakukan etnis Jawa adalah divergensi, sedangkan untuk Tionghoa dan Arab adalah konvergensi. Faktor penyebab terjadinya akomodasi bahasa masyarakat Kota Pekalongan etnis Jawa-Tionghoa-Arab dalam ranah perdagangan adalah status sosial, jarak sosial, usia, dan tujuan tuturan. Fungsi sosial akomodasi bahasa masyarakat Kota Pekalongan etnis Jawa-Tionghoa-Arab dalam ranah perdagangan adalah fungsi representasi, referensi, heuristik, interaksi, regulasi, instrumental, dan personal.

Berdasarkan penelitian tentang gambaran masyarakat di wilayah perbatasan yang sudah dilakukan, perlu ada penelitian kebahasaan tentang akomodasi bahasa di Desa Napan, Kecamatan Bikomi Utara, Kabupaten Timor Tengah Utara (TTU), Provinsi Nusa Tenggara Timur yang berbatasan dengan Distrik Oekusi, Timor Leste.

Penelitian ini akan mengidentifikasi akomodasi bahasa di wilayah perbatasan Indonesia (Nusa Tenggara Timur--Timor Leste dengan memperhatikan karakteristik responden. Masalah dalam penelitian ini adalah mengapa penutur bahasa Dawan berakomodasi, bagaimana arah akomodasi antarbahasa, bagaimana pihak yang berakomodasi berdasarkan jenis kelamin dan kelompok usia? Tujuan penelitian ini adalah untuk mengidentifikasi sebab terjadinya akomodasi, tataran sintaksis yang digunakan dalam akomodasi, dan arah akomodasi antarbahasa. Diidentifikasi pula frekuensi akomodasi bahasa yang digunakan oleh penutur bahasa Dawan berdasarkan karakterisik responden.

\section{LANDASAN TEORI}

Menurut Holmes (2013), tuturan orang berkonvergensi dengan tuturan mitra berbicara mereka. Proses ini disebut dengan akomodasi tuturan. Hal ini terjadi ketika pembicara merasa seperti bagian dari kelompok lawan bicaranya atau pembicara menempatkan diri mereka agar nyaman berkomunikasi. Konvergensi terhadap tuturan 
mitra bicara biasanya merupakan strategi tuturan sopan. Hal ini menyiratkan bahwa tuturan lawan bicara biasanya dapat diterima atau bahkan layak ditiru. Penggunaan tuturan yang sama dan jenis kosakata yang sama merupakan suatu penandaan bahwa peserta tutur berada di kelompok yang sama.

Teori akomodasi dikaitkan dengan penelitian dialektologi diteliti Dhanawaty (2017). Dalam komunikasi dua arah, khususnya komunikasi bersemuka, pewicara umumnya berusaha menyesuaikan diri ke arah mitra wicara, baik secara verbal maupun nonverbal. Penyesuaian diri secara verbal dilakukan pewicara dengan jalan memodifikasi tuturan sehingga menjadi lebih mirip dengan tuturan yang dipakai mitra wicara. Namun, dalam peristiwa wicara tertentu dapat pula terjadi proses yang sebaliknya, yaitu pewicara memodifikasi tuturan sehingga menjadi semakin tidak mirip dengan tuturan mitra wicaranya. Kedua proses akomodasi bahasa tersebut masingmasing disebut konvergensi dan divergensi linguistik (Giles via Trudgill, 1986 dalam Dhanawaty, 2017)

Teori akomodasi dan variasi dialektal dalam bahasa Jawa di perbatasan Yogyakarta-Surakarta diteliti Suyata (2017). Dalam penelitian itu disebutkan bahwa penyebab terjadinya akomodasi bahasa Jawa di perbatasan Yogyakarta-Surakarta adalah meningkatkan efektivitas komunikasi, mengurangi jarak sosial di antara peserta wicara, meningkatkan keakraban, meningkatkan prestise, dan meningkatkan kesantunan. Penelitian tersebut juga menyatakan bahwa teori akomodasi dapat memberikan sumbangan yang besar bagi penelitian dialektologi terutama untuk mengidentifikasi bagaimana dan mengapa variasi bisa terjadi.

Teori akomodasi Holmes (2013) tersebut diacu dalam penelitian ini. Akomodasi adalah penyesuaian yang dilakukan pewicara untuk mengakomodasi tuturannya ketika merespons mitra tutur agar nyaman berkomunikasi. Aspek yang diteliti ialah akomodasi tuturan. Tuturan itu dilihat berdasarkan aspek kebahasaan pada tataran sintaksis yang meliputi leksikal, frasa, ungkapan, dan kalimat.

Tim Redaksi Kamus Besar Bahasa Indonesia (2017) menyatakan bahwa leksikal adalah berkaitan dengan kosakata; frasa adalah gabungan dua kata atau lebih yang bersifat nonpredikatif; ungkapan adalah kelompok kata atau gabungan kata yang menyatakan makna khusus. Moeliono dkk. (2017) menyatakan bahwa kalimat adalah satuan gramatikal terbesar yang mengandung predikat dan mengungkapkan sebuah 
pikiran. Dalam wujud lisan, kalimat ditandai oleh intonasi akhir. Berdasarkan pendapat tersebut, dalam penelitian ini yang dimaksud leksikal ialah berupa kosakata; frasa ialah konstituen yang terdiri atas dua kata atau lebih; dan ungkapan ialah kelompok kata yang menyatakan makna khusus. Kalimat ialah konstruksi gramatikal yang mempunyai intonasi final.

\section{METODE PENELITIAN}

Dalam penelitian ini digunakan metode survei. Metode survei bersifat menggambarkan populasi yang diteliti dan menjelaskan kondisi populasi sedemikian adanya (Mahsun, 2005:223). Teknik pengumpulan data melalui observasi dan wawancara pada responden di wilayah perbatasan. Instrumen pengumpulan data berupa kuesioner, panduan wawancara, alat perekam, dan cacatan lapangan. Kuesioner berisi sejumlah pertanyaan, yaitu karakteristik responden, akomodasi bahasa masyarakat terhadap bahasa daerahnya, akomodasi bahasa masyarakat terhadap bahasa daerah lain yang dianggap penting perannya dalam pergaulan dan lingkungan, akomodasi bahasa masyarakat terhadap bahasa Indonesia, akomodasi bahasa masyarakat terhadap bahasa asing (negara tetangga), dan penguasaan masyarakat terhadap unsur bahasa lain. Panduan wawancara berisi pertanyaan unsur kebahasaan yang mendukung data kualitatif. Populasi adalah seluruh jumlah objek yang diteliti (Amir dkk, 2009:17). Populasi dalam penelitian ini adalah masyarakat di wilayah perbatasan di Desa Napan, Kecamatan Bikomi Utara, Kabupaten Timor Tengah Utara, Provinsi Nusa Tenggara Timur. Sampel dalam penelitian ini berjumlah 72 responden penutur bahasa Dawan yang terdiri atas 36 laki-laki dan 36 perempuan. Responden yang dipilih berdasarkan syarat sebagai berikut, yaitu (1) sehat jasmani dan rohani, (2) dapat berbahasa Indonesia atau dapat berbahasa negara tetangga (Tetun Portu dan Tetun Dili), (3) jujur, (4) memiliki waktu yang cukup, (5) sabar, (6) penutur bahasa ibu (bahasa Dawan), (7) jenis kelamin laki-laki dan perempuan, (8) rentang usia <25 tahun, 26--50 tahun, dan 51 tahun, dan (9) lahir dan berdomisili tetap di lokasi penelitian, di Desa Napan.

Penetapan responden sebagai sampel dengan menggunakan teknik purposive sampling (teknik pengambilan sampel secara sengaja dengan pertimbangan tertentu). Sampel penelitian diambil tidak secara acak tetapi ditentukan peneliti sesuai dengan karakteristik responden yang dijadikan variabel dalam penelitian ini. Analisis data 
dilakukan berdasarkan hasil pengolahan data pada penghitungan frekuensi dan persentase. Selain itu, hasil transkripsi tuturan responden dan mitra tutur Timor Leste dianalisis.

\section{PEMBAHASAN}

Masyarakat di Desa Napan, yaitu suku Siki, Kefi, Nule, Kolo, Eko, dan Eki bertutur dalam bahasa Dawan. Penutur bahasa Dawan, mengakomodasi tuturannya dengan bahasa mitra tutur, yaitu bahasa Indonesia ketika berkomunikasi dengan etnik lain, misalnya suku Jawa, Sunda, Batak, dan Padang atau yang dianggap pendatang. Penutur tidak hanya berbahasa Indonesia, tetapi juga kadang berakomodasi ke bahasa mitra tutur. Akomodasi dilakukan penutur untuk kenyamanan berkomunikasi, keakraban peserta tutur, dan menumbuhkan rasa percaya mitra tutur. Penutur berakomodasi untuk menunjukkan prestasi diri, yaitu penutur mampu berbahasa mitra tutur, penutur bahasa Dawan berakomodasi ke bahasa Tetun Portu atau Tetun Dili. Bahasa Dawan digunakan penuturnya untuk berkomunikasi sesama etnik, misalnya antara suku Siki dan suku Siki atau suku Kefi dan suku Kefi, dan warga eks penduduk Timor-Timur. Berikut adalah contoh unsur bahasa Dawan yang digunakan sehari-hari di antara penutur bahasa Dawan dan penduduk Timor Leste. Unsur bahasa Dawan meliputi leksikal, frasa, ungkapan, dan kalimat. Berikut contoh keempat unsur tersebut.

\section{a. Kosakata}

$\begin{array}{llll}\text { aen } & \text { haek } & \text { 'kaki' } \\ \text { aijoab } & \text { 'berlari' } & \text { hunumu } & \text { 'ruang tengah' } \\ \text { aikanunu } & \text { 'pohon cemara' } & \text { hauh } & \text { 'pohon' } \\ \text { amakoet } & \text { 'bantal' } & \text { holeh } & \text { 'atap rumah' } \\ \text { amaut } & \text { 'rajin } & \text { hudi } & \text { 'pisang' } \\ \text { anin } & \text { 'kaya', } & \text { kalele } & \text { 'cincin' } \\ \text { apehet } & \text { 'angin' } & \text { keon } & \text { 'kamar tidur' } \\ \text { au } & \text { 'pemalas' } & \text { kili } & \text { 'sisir' } \\ \text { benas } & \text { 'saya' } & \text { kleo } & \text { 'sedikit' } \\ \text { bese } & \text { 'parang' } & \text { lian } & \text { 'anak' } \\ \text { bête } & \text { 'pohon mahoni' } & \text { mahe } & \text { 'tikar' } \\ \text { bibi } & \text { 'kain laki-laki' } & \text { manas } & \text { 'matahari' } \\ \text { bijael } & \text { 'kambing' } & \text { matel } & \text { 'hijau' } \\ \text { eno } & \text { 'sapi' } & \text { mau } & \text { 'rumput' } \\ \text { eno polef } & \text { 'pintu' } & \text { meob } & \text { 'kucing' } \\ \text { fas } & \text { 'jendela' } & \text { metan } & \text { 'hitam' } \\ \text { fatu } & \text { 'mencuci' } & \text { mese } & \text { 'satu' } \\ \text { funan } & \text { 'batu' } & \text { molo } & \text { 'kuning' } \\ \text { fois } & \text { 'bulan purnama' } & \text { mof } & \text { 'terbenam' } \\ \text { hal } & \text { 'deret' } & \text { muit } & \text { 'ternak' }\end{array}$




$\begin{array}{llll}\text { mpek } & \text { 'terbit' } & \text { pupun } & \text { 'pohon mangga' } \\ \text { mtasa } & \text { sanje } & \text { 'pohon kersen' } \\ \text { naijan } & \text { 'tanah' } & \text { sbot } & \text { 'rokok', } \\ \text { nafun } & \text { 'rambut' } & \text { sisi } & \text { 'daging', } \\ \text { nakak } & \text { 'kepala', } & \text { soko } & \text { 'sendok' } \\ \text { namfau } & \text { 'banyak' } & \text { sulat } & \text { 'buku' } \\ \text { nehur } & \text { 'kamar mandi' } & \text { tah } & \text { 'makan' }, \\ \text { nete } & \text { 'jembatan' } & \text { teol } & \text { 'sombong' } \\ \text { nimak } & \text { 'tangan', } & \text { tah } & \text { 'makan' } \\ \text { niti } & \text { 'gelang' } & \text { tais } & \text { 'kain perempuan' } \\ \text { noa } & \text { 'pohon kelapa' } & \text { tiun } & \text { 'minum' } \\ \text { nono } & \text { 'sungai' } & \text { tun } & \text { 'tahun' } \\ \text { nuaf } & \text { 'gunung' } & \text { tup } & \text { 'tidur' } \\ \text { oen oek } & \text { 'sawah' } & \text { umeh } & \text { 'rumah' } \\ \text { om } & \text { 'mari' } & \text { umen } & \text { 'sakit' } \\ \text { oto } & \text { 'mobil' } & \text { umoloh } & \text { 'berbicara' } \\ \text { pihu } & \text { 'dinding rumah' } & \text { utan } & \text { 'sayur' } \\ \text { pika } & \text { 'piring' } & \text { usbo } & \text { 'merokok' }\end{array}$

Berdasarkan kelas kata, kosakata bahasa Dawan yang dituturkan penutur bahasa Dawan ada yang berupa numeralia, contoh mese 'satu'; nomina, contoh umeh 'rumah' dan nuaf 'gunung'; pronomina, contoh au 'saya' dan ko 'kamu'; adjektiva, contoh mtasa 'merah' dan molo 'kuning'; verba, contoh tiun 'minum' dan tah 'makan'.

\section{a. Frasa}

$\begin{array}{ll}\text { meop lele } & \text { 'kerja kebun', } \\ \text { nake neme } & \text { 'sakit kepala' } \\ \text { tike nemen } & \text { 'sakit perut' } \\ \text { ume bubu } & \text { 'rumah bulat' } \\ \text { nao hoe } & \text { 'jalan kaki' } \\ \text { bife amataus } & \text { 'gadis cantik' } \\ \text { lian bijael } & \text { 'anak sapi' } \\ \text { mtasa muti } & \text { 'merah putih' }\end{array}$

$\begin{array}{ll}\begin{array}{ll}\text { rumah biru } \\ \text { lian masmeso }\end{array} & \begin{array}{l}\text { 'vem bilu' } \\ \text { 'anak tunggal' } \\ \text { (anak satu- } \\ \text { satunya) }\end{array} \\ \text { saen saon } & \text { 'naik turun' } \\ \text { noa nof } & \text { 'daun kelapa', } \\ \text { mtasa pina } & \text { 'merah muda' } \\ \text { koi fuij } & \text { 'burung hantu' }\end{array}$

Contoh tuturan tersebut berupa frasa nomina (lian bijael 'anak sapi'), frasa adjektiva (mtasa pina 'merah muda'), dan frasa verba (saen saon 'naik turun').

\section{b. Ungkapan}

$\begin{array}{ll}\text { boan dia } & \text { 'selamat pagi' } \\ \text { boan noiti } & \text { 'selamat malam' } \\ \text { la obriga } & \text { 'jangan paksa' } \\ \text { nek seobanit } & \text { 'terima kasih' }\end{array}$

Keempat ungkapan tersebut termasuk unsur vokatif. Vokatif adalah ungkapan seruan, ajakan, dan panggilan. Ungkapan berikut tidak termasuk unsur vokatif.
neon laran ida deit
'satu hati, satu jiwa'
peh mepo makoe soko
'malas kerja, rajin makan'
meup on ate tah on usif
noanof nue nao saen saon
'kerja seperti hamba, makan seperti raja' 'daun kelapa lari naik turun'




\section{c. Kalimat}

Ita nia tinan hira?

Om het nao tabae bola!

Om het nao he taniu!

Om het tah!

Mnao on me?

Au he usbo.

Haru ba haris.

Haru han hudi

Au nao.

Au fanse.

Nao on lele.

Nao on skoll.

Au utoan ko.
'Kamu punya umur berapa?' 'Berapa umur kamu?'

'Mari kita main bola!'

'Mari kita pergi mandi!'

Mari kita makan!'

'Mau pergi ke mana?'

'Saya mau merokok.'

'Saya mau pergi mandi.'

'Saya makan pisang.'

'Saya jalan.'

'Saya pulang.'

'Pergi ke kebun.'

'Pergi ke sekolah.'

'Saya benci kamu.'

Contoh tuturan berupa kalimat sederhana dalam bahasa Dawan yang dituturkan penuturnya. Kalimat tersebut merupakan kalimat tanya (yang menggunakan tanda tanya), perintah (yang menggunakan tanda seru), dan berita (yang menggunakan tanda titik).

Penutur bahasa Dawan di Desa Napan berakomodasi terhadap bahasa Tetun Portu atau Tetun Dili. Bahasa Dawan tidak hanya dituturkan oleh suku Siki, Kefi, Nule, Kolo, Eko, dan Eki yang berada di Desa Napan tetapi juga dituturkan oleh etnik Atoni yang tinggal di Kabupaten Kupang, Kabupaten Ambenu, Kabupaten Timor Tengah Utara, dan Kabupaten Timor Tengah Selatan. Bahasa Dawan (Timor) disebut dengan nama Timor Dawan, Timor Naikono, Timor, Dewan, dan Dawan (Tim Pemetaan Bahasa, 2018:148). Bahasa Tetun Portu atau Tetun Dili merupakan bahasa yang dituturkan oleh masyarakat di Distrik Oekusi. Menurut Simon dan Charles D. Fennig ed. (2017), bahasa Tetun Dili merupakan bahasa pertama masyarakat di Distrik Dili. Nama lain bahasa Tetun Dili adalah Dili Tetum, Tetum, Tetum Dili, Tetum Prasa, Tetum Praca, Tetun, dan Tetun Prasa. Status bahasa Tetun merupakan bahasa resmi dan bahasa nasional menurut Undang-Undang Dasar Republik Demokratis Timor Leste, yaitu Konstitusi Republik Demokratik Timor-Leste, Pasal 13, 2002.

Unsur bahasa Tetun Portu atau Tetun Dili.yang digunakan penutur bahasa Dawan adalah sebagai berikut.

\section{a. Kosakata}

$\begin{array}{llll}\text { un } & \text { 'satu' } & \text { singguh } & \text { 'lima' } \\ \text { dois } & \text { 'dua' } & \text { seis } & \text { 'enam' } \\ \text { tres } & \text { 'tiga' } & \text { septi } & \text { 'tujuh' } \\ \text { quarto } & \text { 'empat' } & \text { viktu } & \text { 'delapan' }\end{array}$




$\begin{array}{llll}\text { novi } & \text { 'sembilan' } & \text { inus } & \text { 'hidung' } \\ \text { des } & \text { 'sepuluh' } & \text { karsa } & \text { 'celana' } \\ \text { onji } & \text { 'sebelas' } & \text { mean } & \text { 'merah' } \\ \text { doji } & \text { 'dua belas' } & \text { mua } & \text { 'makan' } \\ \text { atraji } & \text { 'tiga belas' } & \text { mnao } & \text { 'jalan' } \\ \text { kotorji } & \text { 'empat belas' } & \text { nehan } & \text { 'gigi' } \\ \text { kinji } & \text { 'lima belas' } & \text { faruk } & \text { 'baju' } \\ \text { dijo seis } & \text { 'enam belas' } & \text { ou } & \text { 'saya' } \\ \text { dijo septi } & \text { 'tujuh belas' } & \text { autu } & \text { 'ungkapan untuk } \\ \text { dijo viktu } & \text { 'delapan belas' } & & \text { perempuan cantik' } \\ \text { dijo } \text { novi } & \text { 'sembilan belas' } & \text { hemu } & \text { 'minum' } \\ \text { binti } & \text { 'dua puluh' } & \text { o } & \text { 'kamu' } \\ \text { hira } & \text { 'berapa' } & \text { tinan } & \text { 'umur' } \\ \text { ibun } & \text { 'mulut' } & & \end{array}$

Berdasarkan kelas kata, kosakata bahasa Tetun Portu atau Tetun Dili yang dituturkan penutur bahasa Dawan ada yang berupa numeralia, contoh un 'satu' dan dois “dua'; nomina, contoh karsa 'celana' dan faruk 'baju'; pronomina, contoh ou 'saya' dan $o$ 'kamu'; verba, contoh heтu 'minum' dan mиa 'makan'.

\section{b. Frasa \\ ai funan roja 'bunga mawar' la obriga 'jangan paksa'}

Kedua contoh tuturan berupa frasa nomina (ai funan roja 'bunga mawar') dan frasa verba (la obriga 'jangan paksa').

$\begin{array}{ll}\text { c. Ungkapan } & \\ \text { obrigado } & \text { 'terima kasih', } \\ \text { bondia } & \text { 'selamat pagi' } \\ \text { botardi } & \text { 'selamat siang' } \\ \text { boniiti } & \text { 'selamat malam' } \\ \text { banebe } & \text { 'mau ke mana' } \\ \text { diak kalae } & \text { 'apa kabar' }\end{array}$

Keenam ungkapan tersebut termasuk unsur vokatif. Vokatif adalah ungkapan seruan, ajakan, dan panggilan.

\section{d. Kalimat}
Om nai тиа
'Mari makan.'
Paek sebelu ('Pake baju') 'Pakai baju.'
Om he tnao taniu ('Mari kita pi mandi') 'Mari kita pergi mandi.'
Haw hareja
'Saya pergi ke gereja.'

Keempat contoh tuturan berupa kalimat sederhana dalam bahasa Tetun Portu atau Tetun Dili yang dituturkan penutur bahasa Dawan. Kata paek diartikan 'pake' (bahasa Melayu Kupang) oleh penutur. Kata tersebut dalam bahasa Indonesia berarti 'pakai'. 
Kata tnao diartikan 'pi' (bahasa Melayu Kupang) oleh penutur. Kata tersebut dalam bahasa Indonesia berarti 'pergi'.

Arah akomodasi konvergensi penutur bahasa Dawan terjadi pada bahasa Tetun Portu atau Tetun Dili. Akomodasi bahasa itu terdapat pada tataran leksikal, frasa, kalimat sederhana, dan ungkapan. Responden mengakomodasi bahasa mitra tutur ketika berkomunikasi, tetapi ada responden yang tidak mengakomodasi mitra tutur ketika berkomunikasi. Contoh pertanyaan untuk menjaring data ini ialah ketika berkomunikasi dengan mitra tutur di pasar perbatasan, saya menggunakan bahasa mitra tutur? Pilihan jawaban ialah ya dan tidak. Berdasarkan jenis kelamin dan kelompok usia responden penutur bahasa Dawan, akomodasi bahasa tersebut dapat dilihat pada tabel berikut.

Tabel 1

Akomodasi Bahasa oleh Responden Penutur Bahasa Dawan Berdasarkan Jenis Kelamin

\begin{tabular}{llrrrr}
\hline \multirow{2}{*}{ No. Akomodasi Bahasa } & \multicolumn{4}{c}{ Jenis Kelamin } \\
\cline { 3 - 5 } & & \multicolumn{2}{c}{ Laki-Laki } & \multicolumn{2}{c}{ Perempuan } \\
\cline { 2 - 5 } & & $\mathrm{F}$ & $\%$ & $\mathrm{~F}$ & $\%$ \\
\hline 1. & Tetun Portu atau Tetun Dili & 6 & 8.3 & 7 & 9,7 \\
\hline 2. & Tidak berakomodasi & 30 & 41.7 & 29 & 40,3 \\
\hline & Jumlah & 36 & 50 & 36 & 50 \\
\hline
\end{tabular}

Sumber: Hasil pengolahan data (2017)

Akomodasi bahasa Tetun Portu atau Tetun Dili menunjukkan lebih dominan oleh responden yang berjenis kelamin perempuan, yaitu 9,7\%. Responden yang berjenis kelamin laki-laki, yaitu 8,3\%. Responden yang tidak berakomodasi bahasa adalah responden yang kelamin laki-laki, yaitu 41,7\% dan perempuan, 40,3\%. Dengan demikian, responden yang berakomodasi dan tidak berakomodasi terhadap bahasa Tetun Portu atau Tetun Dili yang berdasarkan jenis kelamin laki-laki dan perempuan adalah hampir sama.

Berdasarkan kelompok usia responden penutur bahasa Dawan akomodasi bahasa Tetun Portu atau Tetun Dili dapat dilihat pada tabel berikut.

Tabel 2

Akomodasi Bahasa oleh Responden Penutur Bahasa Dawan Berdasarkan Kelompok Usia

\begin{tabular}{|c|c|c|c|c|c|c|c|}
\hline \multirow[t]{3}{*}{ No. } & \multirow[t]{3}{*}{ Akomodasi Bahasa } & \multicolumn{6}{|c|}{ Kelompok Usia } \\
\hline & & \multicolumn{2}{|c|}{$<25$ tahun } & \multicolumn{2}{|c|}{$26-50$ tahun } & \multicolumn{2}{|c|}{$>51$ tahun } \\
\hline & & $\mathrm{F}$ & $\%$ & $\mathrm{~F}$ & $\%$ & $\mathrm{~F}$ & $\%$ \\
\hline 1. & Tetun Portu atau Tetun Dili & 4 & 5,5 & 6 & 8,3 & 3 & 4,2 \\
\hline \multirow[t]{2}{*}{2.} & Tidak Berakomodasi & 20 & 27,8 & 18 & 25 & 21 & 29,2 \\
\hline & Jumlah & 24 & 33,3 & 24 & 33,3 & 24 & 33,4 \\
\hline
\end{tabular}

Sumber: Hasil pengolahan data (2017) 
Akomodasi bahasa Tetun Portu atau Tetun Dili tampak lebih dominan oleh responden penutur bahasa Dawan yang berusia 26-50 tahun, yaitu 8,3\%. Selanjutnya, akomodasi bahasa Tetun Portu atau Tetun Dili oleh penutur bahasa Dawan yang berusia $<25$ tahun, yaitu 5,5\% dan > 51 tahun, yaitu 4,2\%. Penutur bahasa Dawan yang tidak berakomodasi bahasa adalah penutur yang berusia $>51$ tahun, yaitu 29,2\%; yang berusia $<25$ tahun, yaitu $27,8 \%$, dan yang berusia $26-50$ tahun, yaitu $25 \%$.

Berdasarkan variabel kelompok usia, pihak yang banyak berakomodasi adalah penutur bahasa Dawan yang berusia $26-50$ tahun, kemudian yang berusia $<25$ tahun, dan yang berusia $>51$ tahun. Generasi kedua (kelompok usia 26-50 tahun) merupakan generasi yang cenderung beradaptasi dalam penggunaan bahasa.

\section{PENUTUP}

Masyarakat di Desa Napan yang bertutur dalam bahasa Dawan dapat berakomodasi karena kenyamanan, keakraban, menumbuhkan rasa percaya mitra tutur, dan meningkatkan prestasi. Penutur bahasa Dawan tersebut berakomodasi terhadap bahasa Tetun Portu atau Tetun Dili pada tataran leksikal, frasa, kalimat, dan ungkapan.

Penutur bahasa Dawan itu ada yang bilingual dan multilingual. Penutur yang bilingual berbahasa Dawan dan Indonesia. Penutur yang multilingual berbahasa Dawan, Indonesia, dan Tetun Portu atau Tetun Dili. Sementara itu, penutur bahasa Dawan cukup positif terhadap bahasa negara tetangga, yaitu bahasa Tetun Portu atau Tetun Dili. Berdasarkan jenis kelamin, penutur bahasa Dawan yang berakomodasi terhadap bahasa Tetun Portu atau Tetun Dili yang perempuan lebih dominan daripada laki-laki. Sementara itu, penutur bahasa Dawan yang tidak berakomodasi terhadap bahasa Tetun Portu atau Tetun Dili berdasarkan jenis kelamin laki-laki lebih dominan daripada perempuan. Berdasarkan kelompok usia, penutur bahasa Dawan yang berakomodasi terhadap bahasa Tetun Portu atau Tetun Dili tampak dominan yang berusia 26-50 tahun dibandingkan dengan yang berusia $<25$ tahun dan $>51$ tahun. Di samping itu, penutur bahasa Dawan yang tidak berakomodasi bahasa adalah penutur yang berusia $>51$ tahun lebih dominan daripada yang berusia $<25$ tahun dan yang berusia $26-50$ tahun.

Berdasarkan jenis kelamin dan kelompok usia, penutur bahasa Dawan yang tidak berakomodasi terhadap bahasa Tetun Portu atau Tetun Dili lebih dominan dibandingkan 
yang berakomodasi terhadap bahasa Tetun Portu atau Tetun Dili. Hal ini disebabkan bahwa masyarakat di Napan dan di Oekusi merupakan masyarakat perbatasan yang memiliki budaya dan nenek moyang yang sama. Kedua warga negara tersebut merupakan masyarakat yang homogen. Selain itu, masyarakat di perbatasan itu memiliki bahasa yang sama, yaitu bahasa Dawan walaupun ada mayarakat Napan yang berakomodasi terhadap bahasa Tetun Portu atau Tetun Dili yang merupakan bahasa nasional di Oekusi, Timor Leste.

Penelitian ini merupakan sebagian kecil aspek kebahasaan. Untuk itu, perlu dikaji aspek lain, seperti fonologi, morfologi, sintaksis, semantik, pragmatik, variasi bahasa, dialektologi, dan linguistik historis komparatif. Temuan penelitian ini dapat menambah khazanah kepustakaan dan meningkatkan ketepatan penggunaan bahasa Indonesia, daerah, dan asing. Selain itu, hasil penelitian ini dapat dijadikan bahan untuk membuat perencanaan bahasa dan kebijakan Badan Bahasa, serta instansi terkait yang menangani masalah kebahasaan di wilayah timur.

\section{DAFTAR PUSTAKA}

Adyana, Sulis dan Fathur Rokhman. (2017). Akomodasi Bahasa pada Masyarakat Kota Pekalongan Etnis Jawa-Tionghoa-Arab dalam Ranah Perdagangan. Jurnal Seloka. Volume 5, Nomor 1. April 2016. https://journal.unnes.ac.id/sju/index.php/seloka/article/view/12755

Aman, dkk. (2016). Akomodasi Aksen, Identiti dan Integrasi Kebangsaan. [http://jurnalbahasa,dbp.my/wordpress/wp-content/uploads/2016/03/3Akomodasi-Aksen.pdf]. Diunduh tanggal 15 Januari 2017.

Amir, Amri dkk. (2009). Metodologi Penelitian Ekonomi dan Penerapannya. Bogor: IPB Press.

Anunu, Yohanis. (2017). Profil Desa Napan. Timor Tengah Utara: Desa Napan.

Badan Pengembangan dan Pembinaan Bahasa. (2011). Penelitian Kekerabatan dan Pemetaan Bahasa Indonesia: Kuesioner Kosakata Dasar dan Kata Budaya Dasar. Jakarta: Kementerian Pendidikan Nasional.

Dhanawaty, Ni Made. (2017). Teori Akomodasi Dalam Penelitian Dialektologi. [http://www.nusapenida.nl/index.php/nusa-penidian/dialect-accommodationdhanawaty-2004]. Diunduh tanggal 15 Januari 2017.

Handayani, Retno. (2016). Kebanggaan Masyarakat Sebatik terhadap Bahasa Indonesia, Bahasa Daerah, dan Bahasa Asing: Deskripsi Sikap Bahasa di Wilayah Perbatasan. Ranah: Jurnal Kajian Bahasa. Volume 5, Nomor 2, Desember 2016. https://doi.org/10.26499/rnh.v5i2.148

Holmes Janet. (2013). An Introduction to Sociolinguistics. Edisi Keempat. London: Routledge.

Mahsun. (2005). Metode Penelitian Bahasa: Tahapan Strategi, Metode, dan Tekniknya. Jakarta: PT Raja Grafindo Persada. 
Majelis Konstituante Timor Leste. (2002). Konstitusi Republik Demokratik Timor-Leste. https://etan.org>constbh. Diunduh 2 Desember 2019.

Moeliono, Anton M. dkk. (2017). Tata bahasa baku bahasa indonesia. Edisi Keempat. Jakarta: Badan Pengembangan dan Pembinaan Bahasa.

Mu'jizah dkk. (2012). Kemampuan dan Penggunaan Bahasa Masyarakat Di Wilayah Perbatasan. Laporan Penelitian. Jakarta: Badan Pengembangan dan Pembinaan Bahasa.

Pemerintah Kabupaten Cianjur. (2011). Pemantapan Wawasan Kebangsaan Dalam Kerangka NKRI di Kabupaten Cianjur. Cianjur: Kantor Kesatuan Bangsa dan Pelindungan Masyarakat.

Simon, F. Gary dan Charles D. Fennig (Ed.). (2017). Ethnologue Languages Of The World. Edisi 20 online-version: http://www.ethnologue.com. Dalas, Texas: SIL International. Diunduh tanggal 11 Juli 2017.

Suyata, Pujiati. (2017). Teori Akomodasi dan Variasi Dialektal Dalam Bahasa Jawa Di Perbatasan Yogyakarta-Surakarta. [http://download.portalgaruda.org/article. php-?] Diunduh tanggal 15 Januari 2017.

Tarmansyah, Umar S. (2012). Potensi dan Nilai Strategis Wilayah Perbatasan Negara: Permasalahan dan Solusinya. Jakarta: Puslitbang Indhan Balitbang Dephan. (Balitbang.dephan.go.id). Diunduh tanggal 15 Januari 2017.

Tim Penelitian Bahasa di Wilayah Perbatasan. (2017). Kuesioner Penelitian Bahasa di Wilayah Perbatasan Indonesia. Jakarta: Badan Pengembangan dan Pembinaan Bahasa.

Tim Pemetaan Bahasa. (2018). Bahasa dan Peta Bahasa di Indonesia. Jakarta: Badan Pengembangan dan Pembinaan Bahasa.

Tim Redaksi Kamus Besar Bahasa Indonesia. (2017). Kamus Besar Bahasa Indonesia. Edisi Kelima. Jakarta: Badan Pengembangan dan Pembinaan Bahasa.

Wirahadi, Umar. (2012). Harmonisnya Warga Di Perbatasan Indonesia Dengan Timor Leste. https://www.jpnn.com/news/harmonisnya-warga-di-perbatasan-indonesia-dengantimor-leste. Diunduh tanggal 3 Mei 2017.

Wawancara dengan Yohanis Anunu (Kepala Desa Napan), Desa Napan, 12 Mei, (2017). 